\title{
Area Analysis of Commodity and Contribution of Coffee to Regional Development in Central Aceh Regency
}

\author{
Virda Zikria \\ Jurusan Agribisnis, Universitas Medan Area \\ e-mail: Firdazikria@gmail.com
}

\begin{abstract}
Coffee is one of commodities that has important role in the national economy in generating foreign exchange, providing employment and industrial raw materials. This study aims to identify the base areas for coffee production and the role of coffee in supporting regional development in Central Aceh Regency. The data used are secondary data for the time period 2015-2019. The data analysis method used are the location quotient analysis, locality, specialization, basic service ratio analysis and regional multiplier. The results showed that the coffee base areas based on production indicators in Central Aceh Regency were all district in Central Aceh Regency except Silih Nara District. Arabica coffee commodity farming is not localized and concentrated in one particular district but spreads in several districts and does not specialize in coffee commodity farming. Coffee farming is able to support regional development activities in Central Aceh Regency.
\end{abstract}

Keywords: Coffee, Location quotient, Localization, Specialization

\section{PENDAHULUAN}

Indonesia adalah salah satu negara pengekspor kopi terbesar di dunia setelah Ghana dan Pantai Gading. Kopi merupakan salah satu komoditas perkebunan yang memiliki peranan penting dalam perekonomian nasional dalam menghasilkan devisa negara, menyerap tenaga kerja serta sebagai penyedia bahan baku industri selain kelapa sawit, karet dan kakao.

Aceh merupakan salah satu provinsi dengan produksi kopi terbesar di Indonesia yang berkontribusi sebesar 10\% dari jumlah produksi kopi nasional. Produksi kopi di Aceh pada tahun 2019 mencapai 71.200 ton dengan luas area penanaman sebesar 125.000 hektar (BPS, 2020). Jenis kopi yang dikembangkan adalah kopi arabika dan robusta. Di mana setiap jenis kopi ini memiliki ciri khas tersendiri. Kopi Arabika mempunyai cita rasa dan harga relatif lebih tinggi dibandingkan dengan kopi jenis robusta serta kadar kafein lebih rendah. Sedangkan kopi jenis robusta cenderung lebih pahit, kadar kafein lebih tinggi hingga harga yang lebih murah. Kabupaten Aceh Tengah merupakan sentra produksi kopi di Aceh yang terkenal dengan sebutan "kopi gayo". Produksi kopi rata-rata selama lima tahun terakhir mencapai 35.447 ton dengan luas area penanaman sebesar 31.484 (BPS, 2020).

Perencanaan wilayah yang memiliki komoditas unggulan dalam pembangunan perlu diperhatikan sehingga komoditas yang dikembangkan didasarkan pada prospek komoditas dan potensi dari wilayah tersebut. Kusmiati \& Windiarti (2011) berpendapat bahwa perencanaan wilayah dalam pengembangan komoditas pertanian merupakan hal yang sangat penting karena 
setiap wilayah memiliki nilai strategis sesuai dengan potensi sumber daya yang terdapat pada masing-masing daerah.

Penelitian tentang analisis pemetaan potensi wilayah sudah pernah dilakukan, antara lain oleh Widyatami (2017) tentang analisis perwilayahan komoditas kedelai di Kabupaten Jember. Harisman (2017) tentang pemetaan potensi wilayah komoditas buah-buahan di Jawa Barat. Susanto et al., (2017) tentang perwilayahan dan strategi pengembangan peternakan kambing di Kabupaten Lumajang.

Berdasarkan uraian di atas maka perlu dibuat penelitian mengenai pemetaan potensi wilayah komoditas kopi di Kabupaten Aceh Tengah. Penelitian ini bertujuan untuk mengidentifikasi wilayah basis produksi komoditas kopi serta peranan kopi dalam mendukung pembangunan wilayah Kabupaten Aceh Tengah.

\section{METODE PENELITIAN}

Data yang digunakan dalam penelitian ini adalah data sekunder dari Badan Pusat Statistik (BPS) nasional Provinsi Aceh serta Kabupaten Aceh Tengah. Data yang dikumpulkan adalah data time series selama lima tahun mulai 2015 sampai 2019. Variabel yang digunakan dalam penelitian ini adalah produksi kopi dan komoditas perkebunan lain yang diusahakan masyarakat pada tiap-tiap wilayah kecamatan di Kabupaten Aceh Tengah.

Metode analisis yang digunakan untuk mengetahui wilayah basis dan non basis komoditas kopi di Kabupaten Aceh Tengah adalah metode analisis Location Quetiont (LQ). Formulasi LQ sebagai berikut (Iswi \& Santoso, 2015):

$$
\mathrm{LQ}_{\mathrm{i}}=\frac{Y i j / Y j}{Y i / Y} \text {. }
$$

Keterangan:

$\mathrm{LQ}_{\mathrm{i}} \quad$ : Location Quetiont

$\mathrm{Y}_{\mathrm{ij}} \quad$ : Produksi kopi di kecamatan i

$\mathrm{Y}_{\mathrm{j}} \quad$ : Produksi komoditas perkebunan di kecamatan $\mathrm{i}$

$\mathrm{Y}_{\mathrm{i}} \quad$ : Produksi kopi di Kabupaten Aceh Tengah

Y : Produksi komoditas perkebunan di Kabupaten Aceh Tengah

Kriteria pengambilan keputusan sebagai berikut:

- Jika nilai $L Q \geq 1$ artinya wilayah tersebut merupakan kecamatan basis komoditas kopi. Produksi komoditas kopi di kecamatan tersebut tidak hanya mampu memenuhi kebutuhan untuk wilayahnya namun dapat mengekspor ke luar wilayah.

- Jika nilai LQ $<1$ artinya wilayah tersebut bukan merupakan kecamatan basis komoditas kopi. Produksinya hanya cukup untuk memenuhi kebutuhan di dalam wilayah kecamatan tersebut.

Metode analisis yang digunakan untuk mengetahui karakteristik penyebaran komoditas kopi di Kabupaten Aceh Tengah adalah analisis lokalita dan spesialisasi. Koefisien lokalita digunakan untuk mengukur penyebaran dari kegiatan pertanian wilayah dengan rumus (Widyatami \& Wiguna, 2017):

$$
\alpha_{\mathrm{i}}=\left[\mathrm{S}_{\mathrm{i}} / \mathrm{N}_{\mathrm{i}}\right]-\left[\sum \mathrm{S}_{\mathrm{i}} / \sum \mathrm{N}_{\mathrm{i}}\right]
$$


Keterangan:

$\alpha \quad$ : koefisien lokalisasi komoditas kopi

Si : Produksi komoditas kopi di kecamatan i

$\mathrm{Ni} \quad$ : Produksi komoditas kopi di Kabupaten Aceh Tengah

$\sum \mathrm{Si} \quad$ : Total produksi komoditas perkebunan di kecamatan i

$\sum \mathrm{Ni} \quad$ : Total produksi komoditas perkebunan di Kabupaten Aceh Tengah

Kriteria pengambilan keputusan:

$\alpha \geq 1$ artinya komoditas kopi terlokalisasi atau terkonsentrasi pada suatu wilayah kecamatan $\alpha<1$ artinya komoditas kopi tersebar di beberapa kecamatan di Kabupaten Aceh Tengah

Koefisien spesialisasi digunakan untuk mengukur tingkat spesialisasi suatu daerah dalam kegiatan tertentu. Formula koefisien spesialisasi sebagai berikut (Nurmalia \& Suwandari, 2019):

$$
\beta_{\mathrm{i}}=\left[\mathrm{Si} / \sum \mathrm{Si}\right]-\left[\mathrm{Ni} / \sum \mathrm{Ni}\right]
$$

Keterangan:

$\beta_{i} \quad$ : Koefisien spesialisasi komoditas kopi

Si : Produksi komoditas kopi di kecamatan i

$\mathrm{Ni} \quad$ : Produksi komoditas kopi di Kabupaten Aceh Tengah

$\sum \mathrm{Si} \quad$ : Total produksi komoditas perkebunan di kecamatan $\mathrm{i}$

$\sum \mathrm{Ni} \quad$ : Total produksi komoditas perkebunan di Kabupaten Aceh Tengah

Kriteria pengambilan keputusan:

$\beta_{\mathrm{i}} \geq 1$ artinya wilayah kecamatan sudah menspesialisasikan pada usaha komoditas kopi

$\alpha<1$ artinya wilayah kecamatan belum menspesialisasikan pada usaha komoditas kopi

Untuk mengetahui peranan komoditas strategis sebagai komoditas basis dalam mendukung perkembangan kegiatan sektor pertanian yang bertujuan untuk kesejahteraan masyarakat digunakan analisis Basic Service Ratio (BSR) dan Regional Multiplier (RM) dengan formula sebagai berikut (Widyatami \& Wiguna, 2017):

Keterangan:

$\mathrm{BSR}=\sum$ Sektor basis $/ \sum$ Non basis

$\mathrm{RM}=\left(\sum\right.$ Sektor basis $+\sum$ Non basis $) / \sum$ Sektor basis

$\sum$ Sektor basis: Jumlah produksi kopi di kecamatan basis Kabupaten Aceh Tengah

$\sum$ Non basis : Jumlah produksi kopi di kecamatan non basis Kabupaten Aceh Tengah

Kriteria pengambilan keputusan:

$\mathrm{RM}>1$ artinya sektor basis memberikan kontribusi yang positif terhadap perkembangan sektor non basis. 


\section{HASIL DAN PEMBAHASAN}

\section{Perkembangan Produksi Kopi}

Kabupaten Aceh Tengah sebagai salah satu sentra komoditas kopi di Provinsi Aceh memberikan kontribusi sebesar 51 persen terhadap produksi kopi di Aceh (BPS, 2020). Komoditas kopi selama kurun waktu tahun 5 tahun dari 2015 sampai 2019 menunjukkan angka yang sedikit fluktuatif namun cenderung meningkat.

Produksi kopi Kabupaten Aceh Tengah pada tahun 2019 sebesar 32.026 ton meningkat hampir dua kali lipat dari lima tahun sebelumnya yaitu 52 persen dibandingkan produksi tahun 2015. Namun untuk luas tanaman perkebunan pada tahun 2019 sebesar 49.366 hektar meningkat hanya sekitar 0.0098 persen dibanding tahun 2015 (BPS, 2020). Peningkatan produksi mengindikasikan bahwa masyarakat setempat memiliki minat yang tinggi dalam membudidayakan tanaman kopi yang mana kopi gayo ini telah memasuki pangsa pasar internasional.

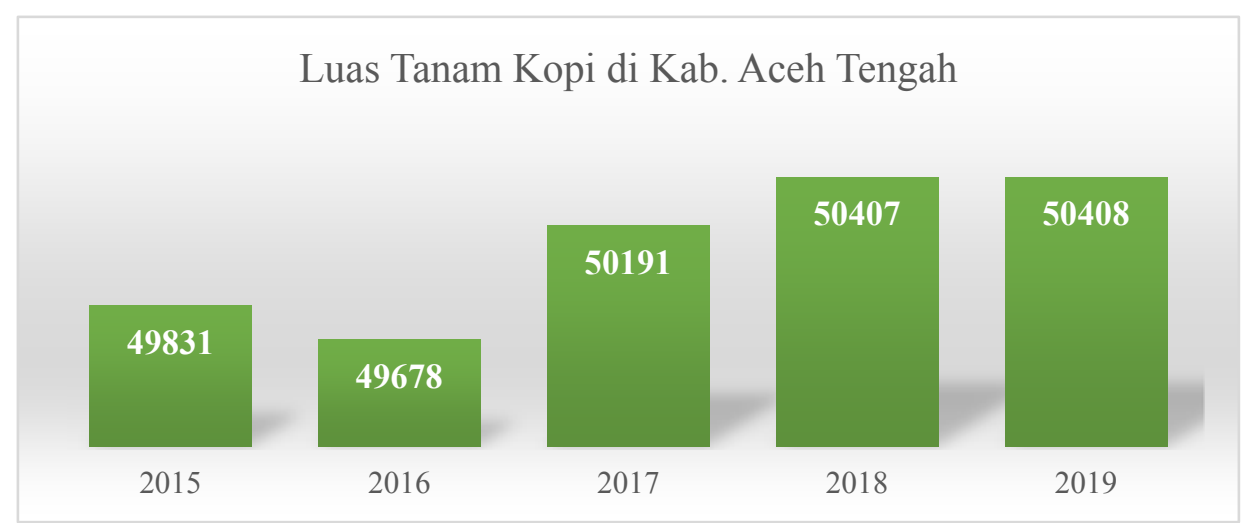

Sumber: BPS, 2020

Gambar 1. Luas Tanam Kopi di Kabupaten Aceh Tengah 2015-2019

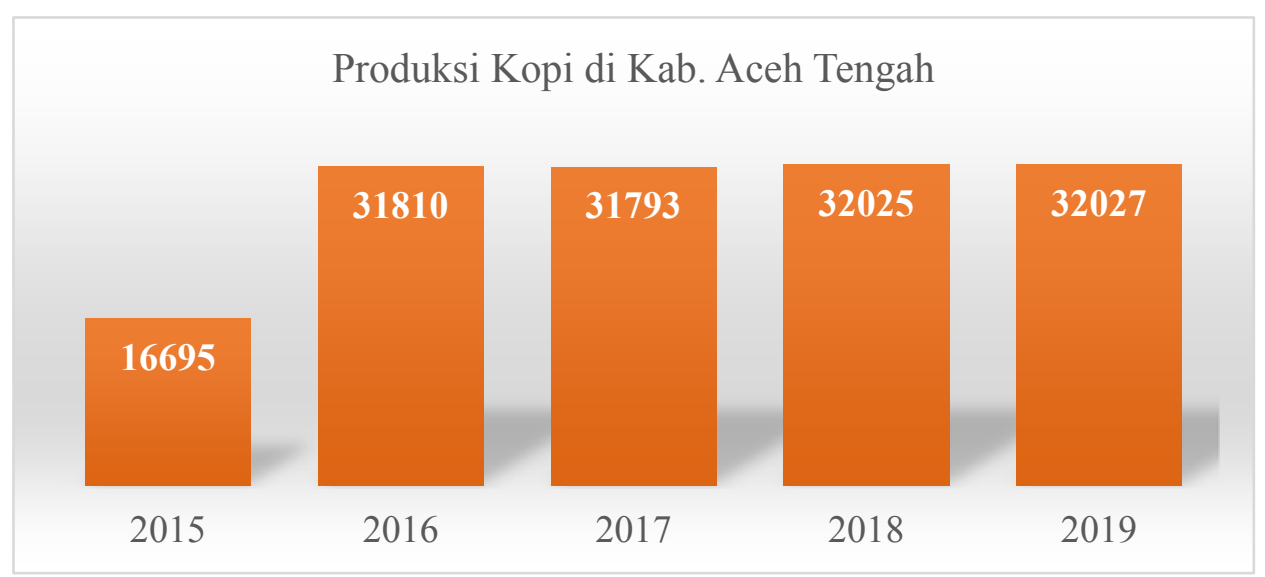

Sumber: BPS, 2020

Gambar 2. Produksi Kopi di Kabupaten Aceh Tengah 2015-2019 


\section{Wilayah Basis Komoditas Kopi}

Perwilayahan komoditas unggulan merupakan penentuan komoditas unggulan yang akan dikembangkan pada masing-masing wilayah kecamatan. Penentuan wilayah basis dan non basis dapat diketahui berdasarkan nilai Location Quetient (LQ) dari komoditas kopi tiap wilayah kecamatan. Hasil analisis LQ komoditas kopi berdasarkan indikator produksi di Kabupaten Aceh Tengah tahun 2015-2019 dapat dilihat pada Tabel 1.

Tabel 1. Hasil Penghitungan Location Quetient (LQ) Wilayah Basis Komoditas Kopi Indikator Produksi di Kabupaten Aceh Tengah Tahun 2015-2019

\begin{tabular}{lcccccc}
\hline \multirow{2}{*}{ Kecamatan } & \multicolumn{7}{c}{ Nilai $\mathbf{L Q}$} \\
\cline { 2 - 7 } & $\mathbf{2 0 1 5}$ & $\mathbf{2 0 1 6}$ & $\mathbf{2 0 1 7}$ & $\mathbf{2 0 1 8}$ & $\mathbf{2 0 1 9}$ & Rata-rata \\
\hline Linge & 1.98 & 1.98 & 2.00 & 1.77 & 1.78 & 1.90 \\
Atu Lintang & 1.87 & 2.17 & 2.20 & 2.08 & 2.08 & 2.08 \\
Jagong Jeget & 1.97 & 2.19 & 2.22 & 2.09 & 2.09 & 2.11 \\
Bintang & 2.12 & 2.14 & 2.17 & 0.64 & 0.64 & 1.54 \\
Lut Tawar & 1.35 & 1.37 & 2.17 & 2.03 & 2.05 & 1.79 \\
Kebayakan & 3.62 & 2.19 & 2.22 & 2.09 & 2.09 & 2.44 \\
Pegasing & 2.02 & 0.46 & 2.20 & 2.07 & 2.07 & 1.76 \\
Bies & 2.25 & 2.26 & 2.22 & 2.09 & 2.09 & 2.18 \\
Bebesen & 1.10 & 0.88 & 2.22 & 2.09 & 2.09 & 1.67 \\
Kuta Panang & 1.35 & 1.34 & 1.47 & 1.29 & 1.29 & 1.35 \\
Silih Nara & 0.14 & 0.15 & 0.16 & 2.03 & 2.03 & 0.90 \\
Ketol & 1.95 & 1.99 & 2.01 & 0.13 & 0.13 & 1.24 \\
Celala & 2.02 & 2.13 & 1.93 & 1.69 & 1.69 & 1.89 \\
Rusip Antara & 2.25 & 2.12 & 2.18 & 2.03 & 2.03 & 2.12 \\
Linge & 1.97 & 1.98 & 2.00 & 1.78 & 1.78 & 1.90 \\
\hline
\end{tabular}

Sumber: BPS Kabupaten Aceh Tengah, 2020 (Data diolah)

Hasil penghitungan LQ menunjukkan bahwa di antara 14 kecamatan di Kabupaten Aceh Tengah terdapat 13 atau hampir semua kecamatan menjadi wilayah basis komoditas kopi arabika. Wilayah basis kopi yang didasarkan indikator produksi memiliki nilai LQ $>1$ yang berarti hanya satu kecamatan yaitu Kecamatan Silih Nara yang memiliki nilai produksi lebih rendah daripada produksi rata-rata Kabupaten Aceh Tengah. Wilayah basis komoditas kopi berdasarkan indikator produksi yang tertinggi adalah Kecamatan Kebanyakan dengan nilai LQ sebesar 2,44, artinya setiap 1 bagian produksi kopi akan digunakan untuk memenuhi kebutuhan Kecamatan Kebayakan sedangkan sisanya sebesar 1,44 bagian untuk memenuhi kebutuhan komoditas kopi di wilayah lain. Komoditas kopi di Aceh Tengah merupakan komoditas perkebunan yang dominan diusahakan oleh masyarakat di kecamatan basis tersebut dengan rata-rata nilai di atas 1 hampir di semua kecamatan. Kecamatan basis tidak hanya mampu mencukupi kebutuhan wilayahnya tetapi juga mampu memenuhi kebutuhan komoditas kopi wilayah lain. Wilayah basis komoditas kopi juga menunjukkan bahwa kopi di Aceh Tengah sangat potensial sehingga pengembangan wilayah tepat untuk mendukung pengembangan komoditas kopi sebagai komoditas perkebunan unggulan di Kabupaten Aceh Tengah. 


\section{Lokalita Komoditas Kopi di Kabupaten Aceh Tengah}

Analisis lokalita digunakan untuk mengetahui apakah komoditas kopi terpusat pada suatu wilayah atau menyebar di beberapa wilayah kecamatan. Hasil penghitungan analisis lokalisasi kopi Aceh Tengah ditunjukkan pada Tabel 2.

Tabel 2. Hasil Penghitungan Lokalisasi Komoditas Kopi menurut Indikator Produksi di Kabupaten Aceh Tengah Tahun 2015-2019

\begin{tabular}{lcccccc}
\hline \multirow{2}{*}{ Kecamatan } & \multicolumn{7}{c}{ Nilai LQ } \\
\cline { 2 - 7 } & $\mathbf{2 0 1 5}$ & $\mathbf{2 0 1 6}$ & $\mathbf{2 0 1 7}$ & $\mathbf{2 0 1 8}$ & $\mathbf{2 0 1 9}$ & Rata-rata \\
\hline Linge & 0.04 & 0.04 & 0.04 & 0.03 & 0.03 & 0.04 \\
Atu Lintang & 0.06 & 0.09 & 0.09 & 0.09 & 0.08 & 0.08 \\
Jagong Jeget & 0.06 & 0.07 & 0.07 & 0.07 & 0.07 & 0.07 \\
Bintang & 0.03 & 0.03 & 0.03 & -0.03 & -0.03 & 0.00 \\
Lut Tawar & 0.01 & 0.01 & 0.02 & 0.02 & 0.02 & 0.02 \\
Kebayakan & 0.07 & 0.03 & 0.03 & 0.03 & 0.03 & 0.04 \\
Pegasing & 0.05 & 0.05 & 0.05 & 0.05 & 0.05 & 0.05 \\
Bies & 0.01 & 0.01 & 0.01 & 0.01 & 0.01 & 0.01 \\
Bebesen & 0.03 & 0.02 & 0.02 & 0.02 & 0.02 & 0.02 \\
Kuta Panang & 0.01 & 0.01 & 0.01 & 0.01 & 0.01 & 0.01 \\
Silih Nara & -0.48 & -0.48 & 0.04 & 0.04 & -0.44 & -0.26 \\
Ketol & 0.03 & 0.04 & 0.04 & -0.45 & -0.45 & -0.16 \\
Celala & 0.03 & 0.03 & 0.03 & 0.02 & 0.02 & 0.03 \\
Rusip Antara & 0.05 & 0.04 & 0.04 & 0.04 & 0.04 & 0.04 \\
\hline
\end{tabular}

Sumber: BPS Kabupaten Aceh Tengah, 2020 (Data diolah)

Hasil analisis lokalisasi berdasarkan indikator produksi menunjukkan bahwa nilai koefisien lokalita masing-masing kecamatan besarnya kurang dari $1\left(\alpha_{\mathrm{i}}<1\right)$ yang berarti bahwa usaha perkebunan komoditas kopi yang diusahakan oleh masyarakat di Kabupaten Aceh Tengah tidak terkonsentrasi atau tidak terpusat di satu wilayah kecamatan saja akan tetapi tersebar di beberapa kecamatan yang ada di Kabupaten tersebut. Kecamatan yang memiliki nilai koefisien lokalita positif ada 12 kecamatan. Hal ini menunjukkan bahwa kecamatan-kecamatan tersebut mampu menghasilkan produksi kopi yang lebih tinggi jika dibandingkan dengan wilayah kecamatan lainnya di Kabupaten Aceh Tengah.

\section{Spesialisasi Komoditas Kopi di Kabupaten Aceh Tengah}

Analisis spesialisasi bertujuan untuk mengetahui spesialisasi suatu wilayah. Spesialisasi ini menunjukkan apakah suatu wilayah hanya mengusahakan satu jenis komoditas pertanian atau lebih. Hasil penghitungan koefisien spesialisasi komoditas kopi arabika dapat dilihat pada Tabel 3. 
Tabel 3. Hasil Penghitungan Spesialisasi Komoditas Kopi menurut Indikator Produksi di Kabupaten Aceh Tengah Tahun 2015-2019

\begin{tabular}{lcccccc}
\hline \multirow{2}{*}{ Kecamatan } & \multicolumn{7}{c}{ Nilai LQ } \\
\cline { 2 - 7 }$(1)$ & $\mathbf{2 0 1 5}$ & $\mathbf{2 0 1 6}$ & $\mathbf{2 0 1 7}$ & $\mathbf{2 0 1 8}$ & $\mathbf{2 0 1 9}$ & Rata-rata \\
\hline Linge & $(2)$ & $(3)$ & $(4)$ & $(5)$ & $(6)$ & $(7)$ \\
Atu Lintang & 0.43 & 0.45 & 0.45 & 0.37 & 0.37 & 0.41 \\
Jagong Jeget & 0.43 & 0.54 & 0.54 & 0.52 & 0.52 & 0.50 \\
Bintang & 0.49 & 0.54 & 0.55 & 0.52 & 0.52 & 0.51 \\
Lut Tawar & 0.16 & 0.17 & 0.53 & -0.17 & -0.65 & 0.14 \\
Kebayakan & 1.15 & 0.54 & 0.53 & 0.50 & 0.50 & 0.37 \\
Pegasing & 0.45 & 0.54 & 0.54 & 0.52 & 0.52 & 0.66 \\
Bies & 0.55 & 0.57 & 0.55 & 0.52 & 0.51 & 0.51 \\
Bebesen & 0.66 & 0.54 & 0.55 & 0.52 & 0.52 & 0.54 \\
Kuta Panang & 0.16 & 0.16 & 0.21 & 0.14 & 0.14 & 0.56 \\
Silih Nara & -0.37 & -0.39 & -0.38 & 0.50 & 0.50 & 0.16 \\
Ketol & 0.42 & 0.45 & 0.46 & -0.41 & -0.41 & -0.03 \\
Celala & 0.45 & 0.52 & 0.42 & 0.33 & 0.33 & 0.10 \\
Rusip Antara & 0.55 & 0.51 & 0.53 & 0.50 & 0.50 & 0.41 \\
\hline Sul BPS Kapd &
\end{tabular}

Sumber: BPS Kabupaten Aceh Tengah, 2020 (Data diolah)

Hasil analisis spesialisasi dengan menggunakan indikator produksi menunjukkan bahwa tidak terdapat wilayah kecamatan yang memiliki nilai indeks spesialisasi lebih besar dari 1 . Hal ini menunjukkan bahwa tidak terdapat kecamatan di Kabupaten Aceh Tengah yang telah menspesialisasikan wilayahnya pada pengusahaan komoditas kopi. Ini menunjukkan keragaman komoditas yang diusahakan oleh masyarakat untuk pemenuhan kebutuhan di wilayah tersebut di mana masyarakat setempat juga masih membudidayakan komoditas lain seperti tebu, kakao dan komoditas perkebunan lainnya.

\section{Daya Dukung Komoditas Kopi Terhadap Pembangunan Wilayah Kabupaten Aceh Tengah}

Peranan komoditas kopi terhadap pembangunan wilayah di Kabupaten Aceh Tengah dapat kita lihat dengan menggunakan analisis Basic Service Ratio (BSR) dan Regional Multiplier (RM). Analisis ini menggunakan perbandingan jumlah wilayah basis dengan jumlah wilayah non basis. Semakin banyak wilayah basis maka semakin meningkatkan pembangunan wilayah. Hasil analisis Basic Service Ratio (BSR) dan Regional Multiplier (RM) menunjukkan peranan yang diberikan wilayah basis terhadap pembangunan wilayah Kabupaten Aceh Tengah.

Hasil analisis Basic Service Ratio (BSR) berdasarkan indikator produksi dapat dilihat pada Gambar 3. Selama kurun waktu 5 tahun nilai BSR lebih besar dari 1 artinya komoditas kopi mampu mendukung kegiatan perkebunan dan pembangunan wilayah Kabupaten Aceh Tengah. Nilai BSR tertinggi pada Tahun 2015 sebesar 11,08 yang menginterpretasikan bahwa setiap 1 bagian produksi komoditas kopi digunakan untuk memenuhi kebutuhan pengembangan 
wilayah basis sedangkan 10,08 bagian digunakan untuk memenuhi kebutuhan pengembangan wilayah non basis.

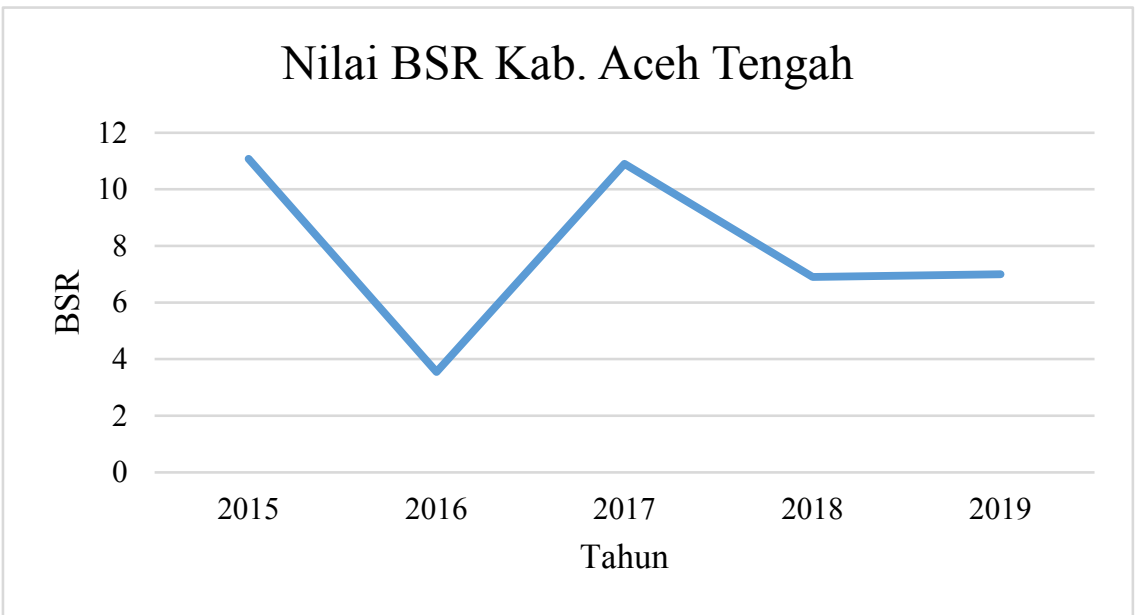

\section{Gambar 3. Nilai BSR Komoditas Kopi Menurut Produksi di Kabupaten Aceh Tengah} Tahun 2015-2019

Melalui analisis Regional Multiplier (RM) dapat diketahui suatu hubungan antara wilayah basis dan efek penambahannya terhadap wilayah lainnya baik secara langsung maupun tidak langsung. Penambahan ini akan memberikan efek berantai terhadap wilayah lainnya walaupun pengaruhnya tidak selalu searah dan dengan besaran yang sama. Hasil analisis Regional Multiplier (RM) selama 5 tahun terakhir dapat dilihat pada Gambar 4.

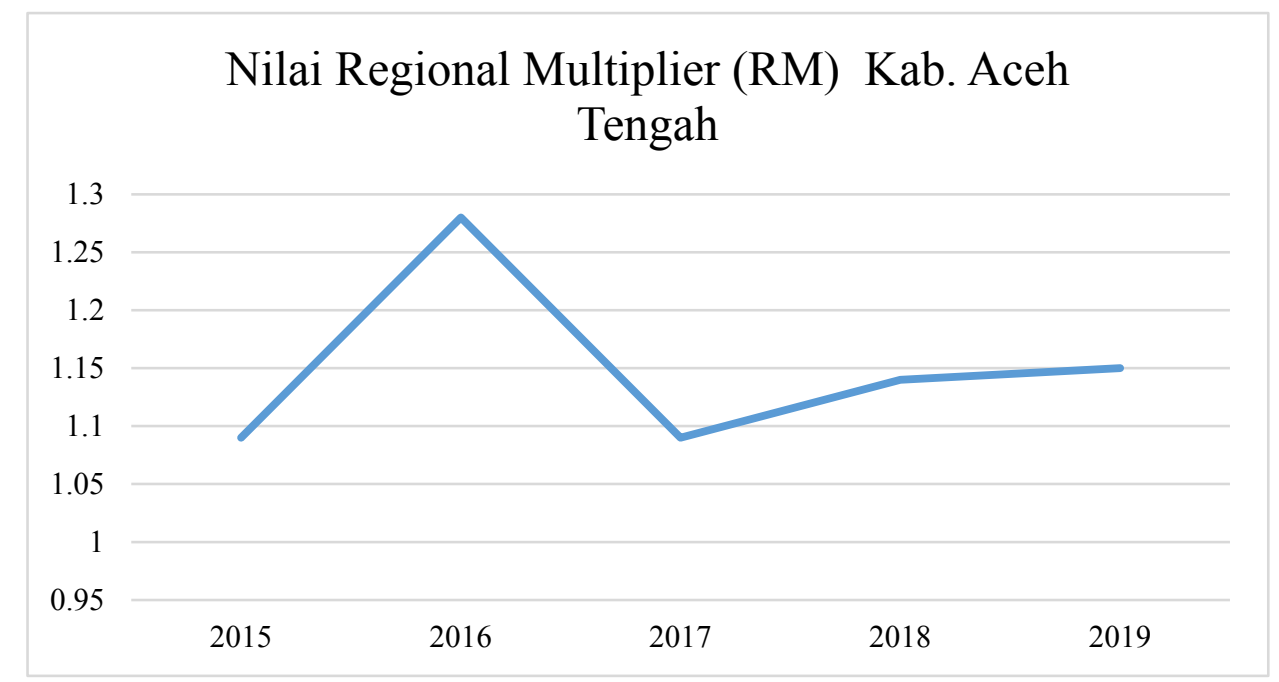

\section{Gambar 4. Nilai RM Komoditas Kopi Menurut Produksi di Kabupaten Aceh Tengah Tahun 2015-2019}

Berdasarkan Gambar 4 dapat diketahui bahwa nilai Regional Multiplier (RM) kopi di Kabupaten Aceh Tengah berdasarkan indikator produksi selama kurun waktu tahun 2015-2019 mempunyai nilai lebih besar dari 1. Nilai RM yang tertinggi terjadi pada tahun 2016 sebesar 1.28 diikuti tahun 2018 dengan besaran nilai 1.14 dan paling kecil tahun 2015 dan 2017 sebesar 
1.09. Nilai 1.2 pada tahun 2019 ini memiliki arti bahwa 1 bagian dari produksi kopi digunakan untuk kebutuhan wilayah basis itu sendiri sedangkan 0.28 bagian lainnya merupakan efek penambahan terhadap wilayah non basis. Nilai Regional Multiplier menggambarkan bahwa keberadaan usaha tani komoditas kopi mendukung kegiatan ekonomi yang timbulkan untuk kecamatan-kecamatan lain yang ada di Kabupaten Aceh Tengah. Multiplier efek atau efek pengganda yang dirasakan berupa peningkatan pendapatan masyarakat dan penyerapan tenaga kerja baik di sektor pertanian maupun sektor lainnya.

\section{KESIMPULAN DAN SARAN}

Daerah basis komoditas kopi di Kabupaten Aceh Tengah adalah semua kecamatan yang ada di Kabupaten Aceh Tengah kecuali Kecamatan Silih Nara sehingga usahatani komoditas kopi tidak terkonsentrasi atau tidak terpusat hanya pada satu wilayah namun tersebar di beberapa wilayah kecamatan yang ada di Kabupaten Aceh Tengah. Usahatani komoditas kopi di wilayah basis tidak menspesialisasikan pada usahatani kopi. Komoditas kopi berperan dalam pembangunan wilayah dan ekonomi Kabupaten Aceh Tengah. Disarankan dengan perannya dalam pembangunan wilayah, pemerintah setempat bisa menggiatkan atau menstimulus petani kopi di Kabupaten tersebut agar lebih meningkatkan hasil produksi serta menjaga kualitas dari kopi tersebut.

\section{DAFTAR PUSTAKA}

BPS. (2020). Provinsi Aceh dalam Angka, 2020. Aceh: Badan Pusat Statistik Provinsi Aceh. - (2020). Kabupaten Aceh Tengah dalam Angka. Takengon: Badan Pusat Statistik Kabupaten Aceh Tengah . (2020). Statistik Kopi Indonesia. Jakarta: Badan Pusat Statistik.

Harisman, K. (2017). The Economic Value of Fruits Commodity in West Java: a Case Study at West Java. In Munich Personal RePEc Archive.

Iswi, A., \& Santoso, B. (2015). Perwilayahan Komoditas Unggulan Tanaman Pangan Berdasarkan Kesesuaian Lahan Kabupaten Tuban. Jurnal Teknik ITS, 4(1), 2-7.

Kusmiati, A., \& Windiarti, R. (2011). Analisis Wilayah Komoditas Kopi Di Indonesia. JSEP (Journal of Social and Agricultural Economics), 5(2), 47-58.

Nurmalia, R., \& Suwandari, A. (2019). Analisis Perwilayahan Dan Kontribusi Komoditas Jeruk Siam Terhadap Perekonomian Kabupaten Banyuwangi. SEPA, 16(1), 85-96.

Susanto, A. D., Soetriono, S., \& Supriono, A. (2017). Analisis Perwilayahan dan Strategi Pengembangan Peternakan Kambing di Kabupaten Lumajang. Sorot, 12(2), 107-120.

Widyatami, L. E., \& Wiguna, A. A. (2017). Analisis Perwilayahan Komoditas Kedelai di kabupaten Jember. Jurnal Ilmiah Inovasi, 17(1), 138-143. 